\title{
DEGRADASI METIL VIOLET MENGGUNAKAN KATALIS ZnO-TiO SECARA FOTOSONOLISIS
}

\author{
Hary Sanjaya, Hardeli, Riri Syafitri \\ Jurusan Kimia, FMIPA, Universitas Negeri Padang \\ e-mail : hary_sanjaya@yahoo.com \\ DOI : 10.24036/eksakta/vol19-iss01/131
}

\begin{abstract}
Research on the degradation of methyl violet has been done by using photosonolysis method. The purpose of this study is to determine how much time the optimum, optimum $\mathrm{pH}$ and the amount of doping TiO2 optimum degrade methyl violet as well as the percent degradation, determined the crystal structure and particle size of the catalyst synthesis of $\mathrm{ZnO}$-TiO2 optimum degrade methyl violet using XRD, determine the value of the band gap Of the optimum $\mathrm{ZnO}$-TiO2 catalyst synthesis in degrading methyl violet using UV-DRS, determining the absorption peak of Zn-O-Ti bonds from optimum $\mathrm{ZnO}$ TiO2 catalyst synthesis in degrading methyl violet using FTIR. The results showed that the optimum time to degrade methyl violet was 45 minutes with 94,1371\% degradation percentage. For $\mathrm{pH}$ variation, the optimum degradation results at $\mathrm{pH} 6$ with percent degradation of $99.2857 \%$. The effect of TiO2 doping variation showed optimum degradation result obtained on doping variation of $\mathrm{TiO} 25 \%$ with percentage degradation of $96,2500 \%$. The optimum catalyst structure of $\mathrm{ZnO}-\mathrm{TiO} 2$ catalyst in degrading methyl violet with XRD is wurtzite (anatase) and the particle size is 42.65 $107.60 \mathrm{~nm}$. The band gap value of the optimum $\mathrm{ZnO}-\mathrm{TiO} 2$ catalyst in degrading methyl violet with $U V$-DRS is $3.18 \mathrm{eV}$. The absorption peak of ZnO-Ti for optimum catalyst $\mathrm{ZnO}$-TiO2 in degrading methyl violet with FTIR is $745.70 \mathrm{~cm}-1$.
\end{abstract}

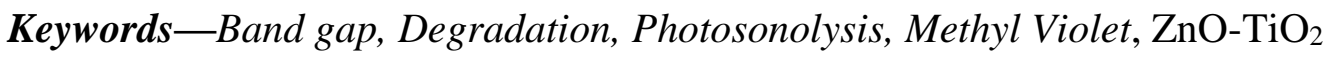

\section{Pendahuluan}

Industri tekstil, percetakan dan pencelupan merupakan penghasil limbah zat warna paling banyak dan dapat merusak lingkungan. Pembuangan limbah zat warna ke sungai akan merusak kehidupan biota air karena sifatnya beracun, dan penyebab kanker, mutagenik bila masuk dalam tubuh manusia (Youssef, et al., 2016).

Zat warna dapat mencegah penetrasi cahaya pada air dan terdegradasi sangat lambat dengan cahaya matahari karena struktur aromatis pada zat warna mempunyai resistensi terhadap pengaruh lingkungan seperti efek ph, suhu dan mikroba (Qodri, 2011 dan Anwar,et al., 2015). Zat warna dapat digolongkan berdasarkan struktur kimianya antara lain; zat warna azo, zat warna quinolin, zat warna xanten, dan zat warna trifenilmetana. Metil violet merupakan salah satu zat warna dari golongan trifenilmetana yang paling banyak digunakan khususnya pada industri tekstil. Metil violet memiliki sifat persisten, sulit dibiodegradasi dan mengandung senyawa anilin yang bersifat toksik, mutagenik dan karsinogen sehingga perlu dilakukan 
penanganan yang serius jika zat tersebut menjadi limbah (Hardeli,et al., 2014).

Berbagai metode telah digunakan untuk menanggulangi permasalahan limbah zat warna diantaranya adalah (1) metode fisika seperti adsorpsi, pengendapan dan osmosis terbalik, (2) metode kimia (klorinasi, ozonasi, fotosonolisis). Diantara metode tersebut yang paling efektif digunakan untuk degradasi zat warna adalah metode fotosonolisis karena merupakan salah satu metode Advanced Oxidation Processes(AOPs) yang mengkombinasikan metode fotolisis dan sonolisis (Rashid, 2011).

Pada fotolisis terjadi interaksi antara molekul air dan radiasi sinar matahari (UV/Visible) sedangkan pada sonolisis dihasilkan gelombang mekanik dengan mempengaruhi efek kavitasi pada air (Safni,et al., 2007). Metode fotosonolisis menggunakan katalis semikonduktor berpotensi menghilangkan/ mendegradasi limbah zat warna lebih cepat (Salehi,et al., 2012).

Zink oksida $(\mathrm{ZnO})$ adalah salah satu semikonduktor yang banyak digunakan sebagai fotokatalis untuk mendegradasi limbah zat warna. $\mathrm{ZnO}$ memiliki efisiensi fotokatalitik berada pada daerah sinar uv (Kasuma, 2012).

Untuk meningkatkan aktifitas fotokatalitik semikonduktor dapat dilakukan dengan mengurangi band gap energi $\mathrm{ZnO}$. Pengurangan band gap $\mathrm{ZnO}$ dapat dilakukan dengan cara menambahankan semikonduktor lain yang mempunyai band gap lebih kecil dari $\mathrm{ZnO}$, salah satunya adalah $\mathrm{TiO}_{2}$.

Degradasi metil violet dengan katalis $\mathrm{ZnO}-\mathrm{TiO}_{2}$ secara fotosonolisis dipengaruhi oleh beberapa faktor yaitu lama waktu degradasi, $\mathrm{pH}$ limbah zat warna dan $\%$ doping $\mathrm{TiO}_{2}$ yang digunakan sebagai katalis. Degradasi metil violet meningkat dengan bertambahnya waktu sampai tercapainya kontak optimum antara foton dengan katalis yang digunakan dan akan mengalami penurunan saat $\mathrm{H}_{2} \mathrm{O}_{2}$ terlalu banyak terbentuk (Youssef, et al., 2016). $\mathrm{pH}$ juga mempengaruhi absorbsi metil violet terhadap katalis, pada $\mathrm{pH}$ rendah metil violet lebih mudah terabsorbs pada permukaan katalis dimana absorbsi yang terlalu besar akan menghambat penyinaran pada katalis yang akan mempengaruhi proses degradasi (Dini, et al., 2014). Jumlah \% doping $\mathrm{TiO}_{2}$ akan mempengaruhi degradasi metil violet, dimana variasi doping akan menghasilkan ukuran partikel dan nilai band gap yang baru yang baru yang bisa meningkatkan aktivitas fotokatalis atau menurunkan aktivitas fotokatalis (Basthomi, 2016).

Penelitian ini dilakukan untuk melihat berapa waktu, $\mathrm{pH}$ dan $\%$ doping $\mathrm{TiO}_{2}$ optimum dalam mendegradasi metil violet dan persen degradasi dari masingmasingnya serta untuk melihat keefektifan antara katalis $\mathrm{ZnO}$ dan $\mathrm{ZnO}$ $\mathrm{TiO}_{2}$ dalam mendegradasi metil violet. Hasil degradasi akan dikarakterisasi menggunakan spektrofotometer UV-Vis dan katalis yang akan digunakan dikarakterisasi dengan XRD, UV-DRS dan FTIR.

\section{METODOLOGI PENELITIAN}

\section{A. Alat dan bahan}

Alat yang digunakan pada penelitian ini yaitu: Kotak fotokatalis dan Ultrasonik, Magnetic Stirer, Oven, Neraca analitis , Furnace, Spektrofotometer UV-Vis, XRD, FTIR, Spektrofotometer UV-DRS, $\mathrm{pH}$ meter, Peralataan gelas

Bahan yang digunakan pada penelitian ini yaitu: Kristal metil violet, $\mathrm{ZnO}, \mathrm{TiO}_{2}$, Metanol p.a, $\mathrm{HCl} 1 \mathrm{M}$, $\mathrm{NaOH} 1 \mathrm{M}$, Aquades.

\section{B. Prosedur Penelitian}




\section{Preparasi katalis $\mathrm{ZnO}-\mathrm{TiO}_{2}$}

Katalis $\mathrm{ZnO}$ sebanyak 0,95 gram dan $\mathrm{TiO}_{2}$ sebanyak 0,05 dilarutkan dalam metanol p.a sebanyak $100 \mathrm{~mL}$, lalu distirer selama 60 menit dan di lanjutkan dengan sonikasi selama 30 menit agar homogen. $\mathrm{ZnO}_{-} \mathrm{TiO}_{2}$ yang telah dilarutkan dipanaskan dalam oven pada suhu $110^{\circ} \mathrm{C}$ selama 60 menit kemudian dikalsinasi selama 30 menit dan didapatkan bubuk $\mathrm{ZnO}^{-\mathrm{TiO}_{2}} \quad 5 \%$. Prosedur yang sama dibuat untuk mendapatkan $\mathrm{ZnO}-\mathrm{TiO}_{2} 10 \%, \mathrm{ZnO}-\mathrm{TiO}_{2}$ $15 \%, \quad \mathrm{ZnO}-\mathrm{TiO}_{2} 20 \%$ dan $\mathrm{ZnO}-\mathrm{TiO}_{2}$ $25 \%$.

\section{Pembuatan Larutan metil violet}

Sebanyak 0,2 gram kristal metil violet dilarutkan dengan sedikit metanol sampai benar-benar larut (Hardeli, et al., 2014), kemudian diencerkan dengan aquades dalam labu ukur $1000 \mathrm{~mL}$ sehingga diperoleh larutan metil violet dengan konsentrasi 200 ppm yang disebut larutan induk. Selanjutnya 50 $\mathrm{mL}$ larutan induk dipipet dan diencerkan dengan aquades sehingga diperoleh larutan metil violet konsentrasi $10 \mathrm{ppm}$.

\section{Degradasi metil violet secara fotosonolisis}

Sebelum degradasi dilakukan, larutan metil violet terlebih dahulu diukur absorbansi maksimumnya menggunakan spektrofotometer UV-Vis dengan rentang panjang gelombang 400-800 nm untuk mengetahui panjang gelombang maksimum $\left(\lambda_{\text {mak }}\right)$ dari metil violet. Dari pengukuran yang dilakukan $\lambda_{\text {mak }}$ dari metil violet adalah $579 \mathrm{~nm}$.

Sampel yang sudah didegradasi diukur absorbansinya pada $\lambda_{\text {mak }}$ dan dihitung persen degradasinya $\left(\begin{array}{ll}\% & \mathrm{D}\end{array}\right)$ menggunakan persamaan berikut:

$$
\% \mathrm{D}=\frac{A_{0}-A_{t}}{A_{0}} \times 100 \%
$$

dengan $A_{0}$ adalah absorbansi sebelum degradasi dan $A_{t}$ adalah absorbansi sesudah degradasi pada waktu $\mathrm{t}$ (Parshetti, et al., 2011).

a. Degradasi metil violet dengan variasi waktu secara fotosonolisis

Larutan metil violet 10 ppm sebanyak $80 \mathrm{~mL}$ dimasukkan kedalam gelas piala $250 \mathrm{~mL}$, kemudian ditambahkan 0,1 gram $\mathrm{ZnO}$, selanjutnya disinari dengan lampu UV dan disonifikasi dengan alat ultrasonik selama 15 menit. Hal yang sama juga dilakukan untuk waktu 30, 45, 60, 75 dan 90 menit.

\section{b. Degradasi metil violet dengan variasi $\mathrm{pH}$ secara fotosonolisis}

Larutan metil violet 10 ppm sebanyak $80 \mathrm{~mL}$ diatur pHnya dengan penambahan $\mathrm{HCl} 1 \mathrm{M}$ dan $\mathrm{NaOH} 1 \mathrm{M}$ menggunakan $\mathrm{pH}$ meter. Larutan divariasikan dengan $\mathrm{pH} 3,4,5,6,7$ dan 8 setelah $\mathrm{pH}$ diatur larutan selanjutnya ditambah 0,1 gram $\mathrm{ZnO}$ kemudian disinari dengan lampu UV dan disonifikasi dengan alat ultrasonik pada waktu optimum degradasi metil violet.

c. Degradasi metil violet dengan variasi \% katalis $\mathrm{ZnO}-\mathrm{TiO}_{2}$ secara fotosonolisis

Larutan metil violet 10 ppm sebanyak $80 \mathrm{~mL}$ diatur pada $\mathrm{pH}$ optimum dan ditambahkan dengan 0,1 gram $\mathrm{ZnO}-\mathrm{TiO}_{2}$ $5 \%$ selanjutnya disinari dengan lampu UV dan disonifikasi dengan alat ultrasonik frekuensi pada waktu optimum degradasi pada metil violet. Hal yang sama juga dilakukan dengan penambahan $\mathrm{ZnO}-\mathrm{TiO}_{2} 10 \%, \mathrm{ZnO}-\mathrm{TiO}_{2}$ $15 \%, \quad \mathrm{ZnO}-\mathrm{TiO}_{2} 20 \%$ dan $\mathrm{ZnO}-\mathrm{TiO}_{2}$ $25 \%$.

\section{Karakterisasi Katalis \\ a. Karakterisasi katalis dengan XRD}


Struktur kristal dan ukuran partikel katalis dianalisa dengan instrumen XRD. Sampel yang akan dikarakterisasi adalah katalis $\mathrm{ZnO}, \mathrm{TiO}_{2}$ dan $\mathrm{ZnO}$ doping $\mathrm{TiO}_{2}$ optimum dari hasil fotodegradasi model metil violetsecara fotosonolisis. Hasil karakterisasi dengan XRD untuk mendapatkan informasi morfologi dan bentuk kristal. Karakterisasi memperlihatkan pengaruh penambahan $\mathrm{TiO}_{2}$ terhadap $\mathrm{ZnO}$. Untuk menentukan stuktur kristal dapat menggunakan persamaan Scherrer:

$$
\mathrm{D}=\frac{k \lambda}{\beta \cos \theta}
$$

dengan $\mathrm{D}$ adalah ukuran kristal, $\mathrm{k}$ adalah konstanta Scherrer untuk kristal berbentuk sferis $(0,94), \lambda$ adalah panjang gelombang sinar-X $(0,154), \beta$ adalah nilai FWHM masing-masing puncak karakteristik, $\theta$ adalah sudut difraksi.

\section{b. Karakterisasi katalis dengan UV-DRS}

Katalis $\mathrm{ZnO}, \mathrm{TiO}_{2}$ dan $\mathrm{ZnO}$ doping $\mathrm{TiO}_{2}$ optimum untuk degradasi dikarakterisasi dengan UV-DRS untuk melihat band gap energi masingmasingnya. Energi band gap diperoleh dengan mengubah besaran \% R kedalam faktor Kubelka-Munk $(\mathrm{F}(\mathrm{R}))$.

$$
F R=\frac{(1-R)^{2}}{2 R}
$$

Metode Kubelka-Munk dapat digunakan untuk mencari band gap $(\mathrm{Eg})$, dimana:

$$
\mathrm{Eg}=\mathrm{hv}=\frac{\mathrm{h} \mathrm{c}}{\lambda}
$$

Energi celah pita diperoleh dari grafik hubungan anatara hv $(\mathrm{eV})$ vs $\left(\mathrm{F}\left(\mathrm{R}^{\prime}\right) \mathrm{hv}\right)^{1 / 2}$. Eg adalah energi band gap $(\mathrm{eV}), \mathrm{h}$ adalah konstanta planck $\left(6,626 \times 10^{-34} \mathrm{Js}\right), \mathrm{c}$ adalah kecepatan cahaya $\left(1,872452 \times 10^{36}\right)$ dan $\lambda$ adalah panjang gelombang (nm). Energi band gap semikonduktor adalah besarnya hv pada saat $F(R) h v)^{1 / 2}=0$, yang diperoleh dari persamaan regresi linier kurva tersebut (Fiolida, 2016).

\section{c. Karakterisasi katalis dengan FTIR}

Katalis $\mathrm{ZnO}, \mathrm{TiO}_{2}$ dan $\mathrm{ZnO}-\mathrm{TiO}_{2}$ optimum dikarakterisasi dengan FTIR. Hasil karakterisasi dengan FTIR untuk mendapatkan informasi gugus yang terdapat pada masing-masing katalis.

\section{HASIL DAN PEMBAHASAN}

\section{A. Degradasi Metil Violet dengan Variasi Waktu secara Fotosonolisis}

Waktu adalah salah satu faktor yang mempengaruh degradasi metil violet. Pengaruh waktu untuk degradasi metil violet divariasikan pada waktu 15, 30, $45,60,75$ dan 90 menit yang ditunjukkan pada Gambar 1. Pada Gambar 1 terlihat bahwa degradasi metil violet meningkat dengan bertambahnya waktu degradasi dalam waktu 75 menit karena semakin lama waktu penyinaran dan sonikasi jumlah $\cdot \mathrm{OH}$ yang dihasilkan untuk mendegradasi semakin banyak. Tetapi degradasi lebih lanjut pada waktu 90 menit menunjukkan degradasi metil violet mengalami penurunan dari 95,9348\% - 93,4768\%. Penurunan persen degradasi metil violet pada waktu 90 menit dikarenakan banyaknya $\mathrm{H}_{2} \mathrm{O}_{2}$ yang dihasilkan pada proses sonikasi yang kemudian bereaksi dengan $\cdot \mathrm{OH}$ menghasilkan radikal hidroperoksi $(\cdot \mathrm{OOH})$ (Youssef, et al., 2016).Dari hasil penelitian kondisi optimum untuk degradasi metil violet adalah 45 menit. 


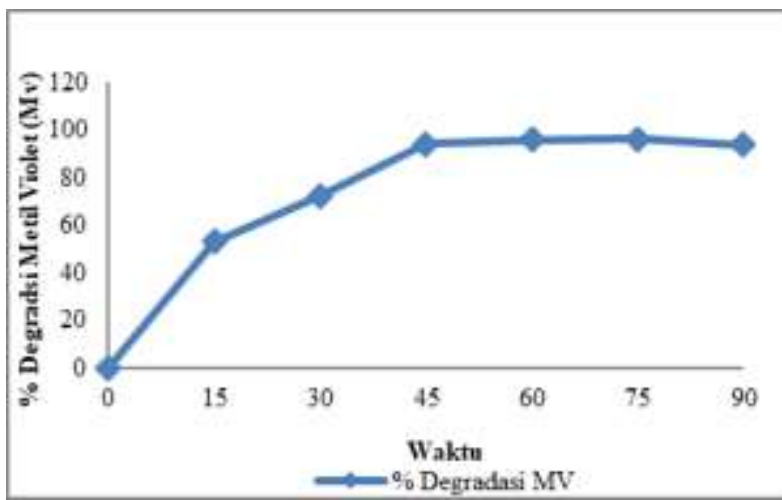

Gambar 1. Kurva pengaruh waktu terhadap persen degradasi metil violet

\section{B. Degradasi Metil Violet dengan Variasi pH secara Fotosonolisis}

Selain waktu degradasi, $\mathrm{pH}$ juga merupakan faktor yang mempengaruhi degradasi metil violet. Pengaruh $\mathrm{pH}$ untuk degradasi metil violet divariasikan pada $\mathrm{pH} 3,4,5,6,7,8$ yang ditunjukkan pada Gambar 2. Dari Gambar diketahui bahwa degradasi metil violet meningkat dari $\mathrm{pH}$ 3-6 dengan persen degradasi terbaik diperoleh pada $\mathrm{pH}$ 6. Meningkatnya persen degradasi dari $\mathrm{pH}$ 3-6 disebabkan ketika $\mathrm{pH}$ dinaikkan maka permukaan katalis $\mathrm{ZnO}$ akan bermuatan negatif oleh ion hidroksil yang teradsorpsi yang mempromosikan pembentukkan $\bullet \mathrm{OH}$ sehingga laju degradasi meningkat (Suhail, et al., 2015). Kecilnya persen degradasi metil violet pada $\mathrm{pH}$ asam disebabkan karena pada $\mathrm{pH}$ tersebut terjadi adsorpsi yang tinggi dari metil violet pada katalis $\mathrm{ZnO}$ sehingga menghambat penyerapan sinar UV pada katalis yang menyebabkan $\cdot \mathrm{OH}$ yang dihasilkan berkurang(Dini, et al., 2014). Peningkatan $\mathrm{pH}$ lebih lanjut pada $\mathrm{pH} 7$ dan 8 menunjukkan penurunan persen degradasi dari 99,2857 \% - 97,1429\%. Hal ini disebabkan telah terjadinya kontak optimum antara $\mathrm{ZnO}$ dan metil violet dan banyaknya $\cdot \mathrm{OOH}$ yang terbentuk, selain itu rekombinasi dari
-OH juga mempengaruhi penurunan persen degradasi metil violet.

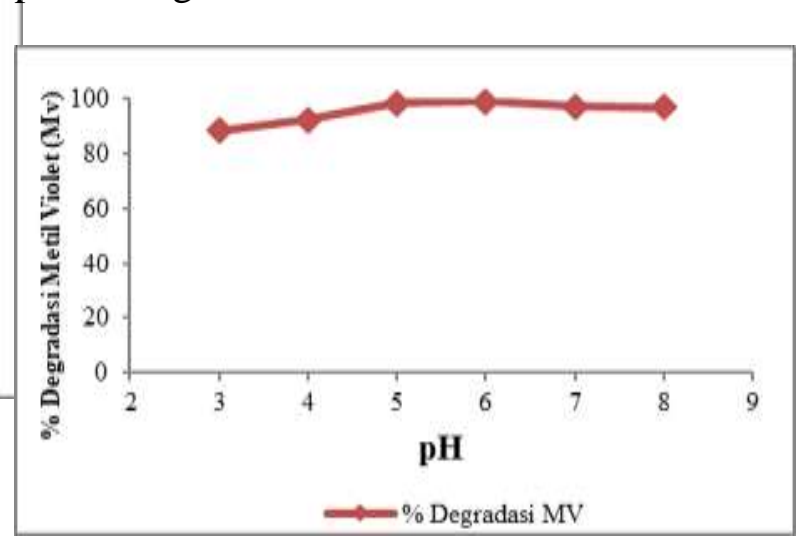

Gambar 2. Kurva pengaruh $\mathrm{pH}$ terhadap persen degradasi metil violet

\section{Degradasi Metil Violet dengan \\ Variasi \% Katalis $\mathrm{ZnO}-\mathrm{TiO}_{2}$ secara Fotosonolisis}

Degradasi metil violet juga dipengaruhi oleh variasi \% doping $\mathrm{TiO}_{2}$.Degradasi metil violet dilakukan menggunakan katalis $\mathrm{ZnO}$ $\mathrm{TiO}_{2}$ dengan variasi doping 5\%, 10\%, $15 \%, 20 \%$ dan $25 \%$ yang ditunjukkan pada Gambar 3. Gambar 3 menunjukkan bahwa persen degradasi metil violet menurun dengan penambahan variasi doping $\mathrm{TiO}_{2}$. Persen degradasi optimum diperoleh pada variasi doping $\mathrm{TiO}_{2} 5 \%$ dengan persen degradasi 96,2500 \%. Penurunan persen degradasi ini dikarenakan penambahan dari jumlah doping $\mathrm{TiO}_{2}$ pada katalis $\mathrm{ZnO}$ yang membuat zat warna semakin banyak terserap pada permukaan katalis.

Akan tetapi persen degradasi dengan menggunakan katalis ${\mathrm{ZnO}-\mathrm{TiO}_{2}}_{2}$ lebih rendah jika dibandingkan dengan menggunakan katalis $\mathrm{ZnO}$. Penyebab turunnya persen degradasi dari metil violet pada katalis $\mathrm{ZnO}-\mathrm{TiO}_{2} 5 \%$ jika dibandingkan dengan degradasi menggunakan katalis $\mathrm{ZnO}$ adalah karena pengaruh dari $\mathrm{pH}$ larutan metil volet yang digunakan untuk mendegradasi. Katalis $\mathrm{ZnO}$ yang didoping $\mathrm{TiO}_{2} \quad 5 \%$ 
mengalami penurunan aktivitas fotokatalis pada $\mathrm{pH}$ yang tinggi $(\mathrm{pH} 6)$ karena pada $\mathrm{pH}$ tinggi aktivitas fotokatalis dari $\mathrm{TiO}_{2}$ akan menurun disebabkan banyaknya metil violet yang teradsorpsi sehingga $\mathrm{TiO}_{2}$ tidak terdistribusi pada permukaan metil violet (Dini, et al., 2014 \& Herrmann, 1999).
48,$00 ; 56,53 ; 62,80 ; 67,89 ; 69,03$ yang merupakan puncak karakterisasi dari struktur kristal wurtzite (anatase).

Hasil pengukuran dengan XRD juga dapat digunakan untuk menentukan ukuran partikel dari masing-masing katalis menggunakan persamaan scherrer yang ditunjukan pada Tabel 1 .

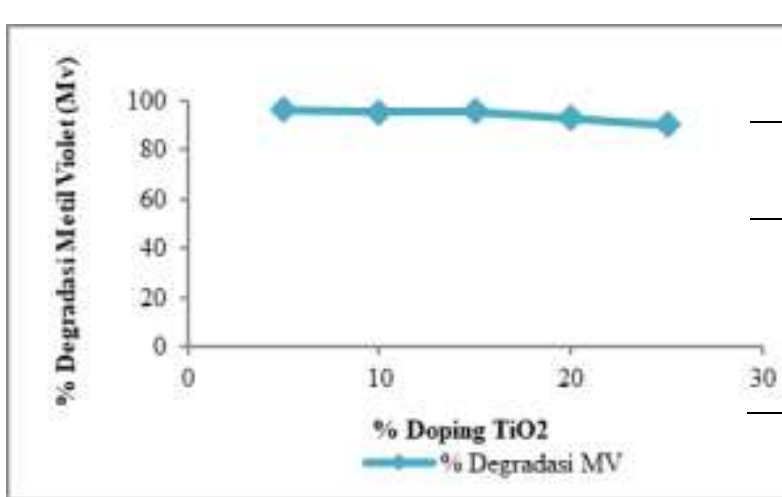

Gambar 3. Kurva pengaruh jumlah doping $\quad \mathrm{TiO}_{2} \quad$ terhadap degradasi metil violet

\section{Karakterisasi Katalis}

\section{Menggunakan XRD}

Karakterisasi menggunakan XRD bertujuan untuk melihat struktur kristal dan ukuran partikel katalis $\mathrm{ZnO}, \mathrm{TiO}_{2}$, ${\mathrm{ZnO}-\mathrm{TiO}_{2}}_{5 \%} \%$. Hasil pengukuran dengan XRD akan memberikan pola difraktogram yang digunakan untuk analisa struktur kristal yang ditunjukkan pada Gambar 4. Pola difraktogram pada Gambar 4 memberikan puncak karakteristik dari masing-masing katalis pada posisi $2 \theta\left(^{\circ}\right)$. Puncak karakteristik untuk $\mathrm{TiO}_{2}$ pada posisi $2 \theta\left(^{\circ}\right)=25,26$; 37,$72 ; 47,97 ; 53,83 ; 55,00 ; 62,62$ yang merupakan puncak karakteristik untuk struktur kristal anatase. Puncak karakteristik untuk ZnOpada posisi $2 \theta\left(^{\circ}\right)$ $=31,72 ; 34,37 ; 36,20 ; 47,48 ; 56,54$; 62,$80 ; 67,89$ dan 69,03 yang merupakan puncak karakteristik dari struktur kristal wurtzite. Untuk katalis $\mathrm{ZnO}-\mathrm{TiO}_{2} \quad 5 \%$ didapatkan puncak karakteristik pada $2 \theta\left(^{\circ}\right)=31,71 ; 34,36 ; 36,19 ; 47,48 ;$
Tabel 1. Ukuran partikel katalis $\mathrm{ZnO}$, $\mathrm{TiO}_{2}, \mathrm{ZnO}-\mathrm{TiO}_{2} 5 \%$

\begin{tabular}{|c|c|}
\hline Katalis & $\begin{array}{c}\text { Range ukuran partikel } \\
\text { (nm) }\end{array}$ \\
\hline \multirow{4}{*}{$\begin{array}{c}\mathrm{ZnO} \\
\mathrm{TiO}_{2} \\
\mathrm{ZnO}-\mathrm{TiO}_{2} \\
5 \%\end{array}$} & $48,50-80,70$ \\
\hline & $48,96-83,81$ \\
\hline & $42,65-107,60$ \\
\hline & \\
\hline
\end{tabular}
pada ukuran partikel $\mathrm{ZnO}$ dan $\mathrm{TiO}_{2}$. Ukuran partikel mempengaruhi aktivitas katalis dalam mendegradasi metil violet, ukuran partikel yang besar akan memperluas permukaan katalis $\mathrm{ZnO}$ $\mathrm{TiO}_{2}$ sehingga mengurangi laju degradasi.

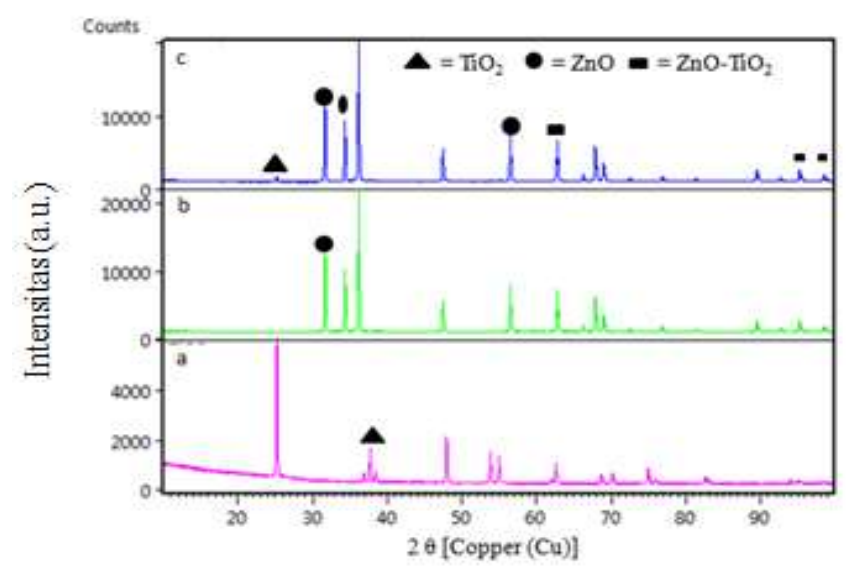

Gambar 4. Difraktogram (a) $\mathrm{TiO}_{2}$ (b) $\mathrm{ZnO}$ dan (c) $\mathrm{ZnO}-\mathrm{TiO}_{2} 5 \%$

\section{Menggunakan $U V-D R S$}

Karakterisasi dengan UV-DRS bertujuan untuk melihat band gap dari masing-masing katalis yang digunakan untuk mendegradasi metil violet. Nilai band gap fotokatalis didapatkan dengan melakukan ekstrapolasi dari bagian 
grafik yang membentuk garis lurus menuju sumbu $\mathrm{x}(\mathrm{hv})\left(\mathrm{y}(\mathrm{F}(\mathrm{R}) \mathrm{hv})^{1 / 2}\right)=$ $0)$. Grafik nilai band gap dari masingmasing katalis ditunjukkan pada Gambar 5.

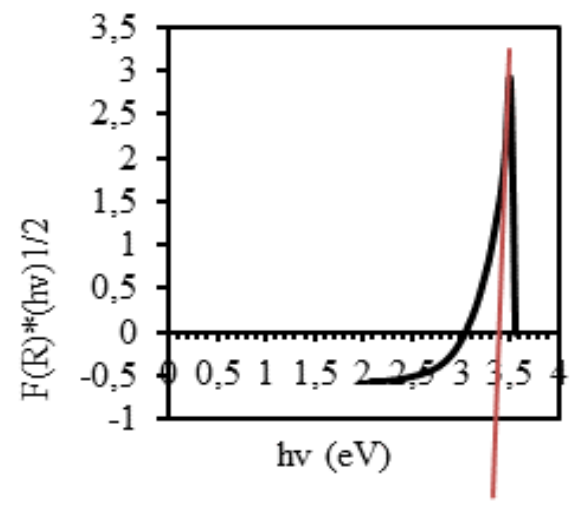

a
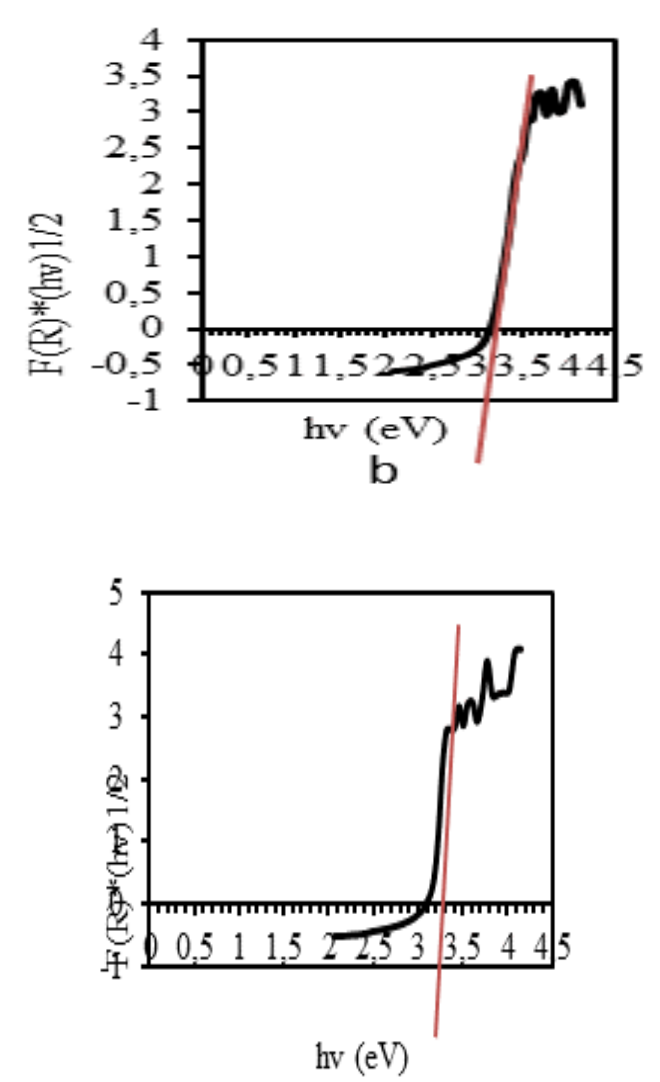

Gambar 5. Grafik nilai band gap (a) $\mathrm{ZnO}$, (b) $\mathrm{TiO}_{2}$ dan (c) $\mathrm{ZnO}-$ $\mathrm{TiO}_{2} 5 \%$.

Dari Gambar 5 didapatkan nilai band gap yang dimiliki $\mathrm{ZnO}-\mathrm{TiO}_{2} 5 \%$ untuk mendegradasi metil violet pada kondisi optimum yaitu 3,18 eV.

\section{Menggunakan FTIR}

Karakterisasi dengan FTIR bertujuan untuk analisis pita serapan dari vibrasi gugus fungsi katalis $\mathrm{ZnO}, \mathrm{TiO}_{2}$, $\mathrm{ZnO}_{-}-\mathrm{TiO}_{2}$ 5\%. Hasil karakterisasi dengan FTIR ditunjukkan pada Gambar 6. Karakterisasi $\mathrm{ZnO}$ dengan FTIR menunjukkan puncak serapan dari $\mathrm{Zn}-\mathrm{O}$ adalah pada daerah bilangan gelombang $490,07 \mathrm{~cm}^{-1}$. Karakterisasi $\mathrm{TiO}_{2}$ dengan FTIR memperlihatkan puncak serapan tajam pada daerah bilangan gelombang $693,72 \mathrm{~cm}^{-1}$. Karakterisasi $\mathrm{ZnO}-\mathrm{TiO}_{2} 5 \%$ dengan FTIR menunjukkan puncak serapan pada bilangan gelombang $745,70 \mathrm{~cm}^{-1}$ yang merupakan puncak serapan dari $\mathrm{Zn}-\mathrm{O}-\mathrm{Ti}$.

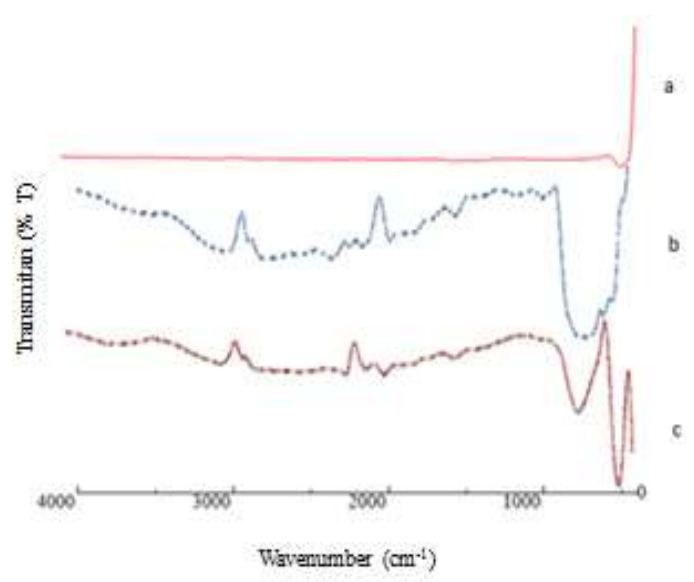

Gambar 6. Spektra FTIR (a) ZnO, (b) $\mathrm{TiO}_{2}$ dan (c) $\mathrm{ZnO}-\mathrm{TiO}_{2} 5 \%$

\section{KESIMPULAN}

Berdasarkan hasil penelitian waktu optimum untuk degradasi metil violet adalah 45 menit dengan persen degradasi 94,1371\%, pH optimum adalah $\mathrm{pH} 6$ dengan persen degradasi 99,2857\%, variasi doping $\mathrm{TiO}_{2}$ optimum yaitu pada doping $\mathrm{TiO}_{2} 5 \%$ dengan persen degradsi 
96,25\% dengan struktur kristal wurtzite (anatase), ukuran partikel 42,65-107,60 $\mathrm{nm}$, band gap 3,18 eV dan puncak serapan ikatan Zn-O-Ti pada bilangan gelombang $745,70 \mathrm{~cm}^{-1}$.

\section{REFERENSI}

Anwar, Devi Indah. 2015. Synthesis of $\mathrm{Fe}^{-\mathrm{TiO}_{2}}$ Composite as a Photocatalyst for Degradation of Methylene Blue. Procedia Chemistry 17: 49-54.

Basthomi, Ibnu Abas Al. 2016. "Sintesis, Karakterisasi dan Uji Aktivitas Fotokatalis Titanium Dioksida (TiO2) Anatas Terdoping Vanadium (III) Menggunakan Metode Sonikasi.' Skripsi, Univirsitas Islam Negeri Maulana Malik Ibrahim Malang, Malang.

Dini, Eka Wahyu Putri dan Sri Wardhani. 2014. Degradasi Metilen Biru menggunakan Fotokatalis ZnO-Zeolit. Chem Prog. Vol 7. No 1.

Hardeli., Afrianti Ramadhani., Desy Kurniawati., Nopri Andriko., Hary Sanjaya. 2014. Degradasi Methil Violet dan Methilen Blue oleh Fotokatalis TiO2. Eksakta. Vol 1.

Harnum, Belina. 2009. "Degradasi Methyl Violet secara Fotolisis dan Sonolisis dengan Katalis $\mathrm{TiO} 2 /$ SiO2." Skripsi, Universitas Negeri Padang, Padang, Indonesia.

Herrmann, J. M. 1999. Heterogeneous Photocatalysis: Fundamentals and Applications to the Removal of Various Types of Aqueous Pollutants. J. Catalysis.Vol.53.

Kasuma, Nola Yulia. 2012.

"'Penggunaan Komposit $\mathrm{ZnO}-\mathrm{CuO}$ yang Disintesis secara Sonochemistry yang digunakan sebagai Katalis untuk Fotodegradasi Metil Orange dan Zat Antibakteri.” Skripsi,
Universitas Andalas. Padang, Indonesia.

Rashid, Md Mamunur dan Chikashi Sato. 2011. Photolysis, Sonolysis, and Photosonolysis of Trichloroethane (TCA), Trichloroethylene (TCE) and Tetrachloroethylene (PCE) Without Catalyst. Water Air Soil Pollut. Vol 216: 429-440.

Parshetti, G. K., Parshetti, S. G., Telke, A. A., Kalyani, D. C., Doong, R. A. dan Govindwar, S. P. 2011. Biodegradation of Crystal Violet by Agrobacteriumradiobacter. Journal of Environmental Science. Vol.23.No. 8

Qodri, A. A. 2011. "Fotodegradasi Zat Warna Remazol Yellow FG dengan Fotokatalis Komplit TiO2/SiO2." skripsi jurusan kimia FMIPA Universitas Sebelas Maret,Surakarta.

Safni., Fardila Sari., Maizatisna dan Zulfarman. 2007. Degradasi Zat Warna Methanil Yellow Secara Sonolisis dan Fotolisis Dengan Penambahan TiO2 Anatase. Jurnal Sains Materi Indonesia.Vol 11. No 1.

Salehi, Marziyeh Hassan Hashemipour., Mohammad Mirzaee. 2012. Experimental Study of Influencing Factors and Kinetics in Catalytic Removal of Methylene Blue with $\mathrm{TiO} 2$ Nanopowder. American Journal of Environmental Engineering; 2(1): 1-7

Suhail, Falah Shreef Abed., Muthana Saleh Mashkour., Deemah Saeb. 2015. The Study On Photo Degradation Of Crystal Violet By Polarographic Technique. International Journal of Basic \& Applied Sciences IJBAS-IJENS Vol 15. No 3

Wardiyati, Siti., Adel Fisli., Saeful Yusuf. 2014.Sintesis Nanokatalis 
TiO2 Anatase dalam Larutan Elektrolit dengan Metode Sol Gel. Jurnal Sains Materi Indonesia.

Youssef, N. A., Seham A. Shaban., Fatma A. Ibrahim., Aya S. Mahmoud. 2016. Degradation of Methyl Orange using Fenton catalytic reaction. Egypt. J. Petrol. 